\title{
Antimitotic Activity of Cayratia trifolia Ethanol Extract on Zygote Cells of Tripneustes gratilla
}

\author{
Eva Feriadi ${ }^{1}$, Wahyuni ${ }^{1}$, Muhammad I. Yusuf ${ }^{2}$ \\ ${ }^{1}$ Faculty of Pharmacy, Halu Oleo University, Kendari, South Sulawesi, Indonesia \\ ${ }^{2}$ Kendari Academy of Medical Analysis, Kendari, South Sulawesi, Indonesia
}

\begin{abstract}
Cancer is a devastating disease characterized by abnormal cell growth. Due to several safety issues associated with current cancer treatment, identification of new strategies for cancer therapy is considered necessary. Natural substances in plants and fruits have the potentials to be developed as anticancer drugs. One of them is Cayratia trifolia (C. trifolia). This study was aimed to determine the cytotoxic activity of stem and leaf ethanol extract of $C$. trifolia against zygote cells of sea urchin or Tripneustes gratilla (T. gratilla). Extraction of stem and leaf of $C$. trifolia was conducted using maceration method in ethanol solvent. Thin layer chromatography was performed to screen phytochemicals contained in the extract. Zygote of $T$. gratilla was used to conduct antimitotic activity test. We found that stem and leaf ethanol extract had $\mathrm{IC}_{50}$ of $169.82 \mu \mathrm{g} / \mathrm{ml}$ and $208.92 \mu \mathrm{g} / \mathrm{ml}$, respectively. In comparison with positive control of vincristine which had $\mathrm{IC}_{50}$ value of $3.23 \times 10^{-3} \mu \mathrm{g} / \mathrm{ml}$ (very strong category), this extract showed moderate antimitotic activity. In conclusion, $C$. trifolia is potential to be developed as anticancer treatment.
\end{abstract}

Keywords: cancer, Cayratia trifolia, antimitotic

\section{Introduction}

Cancer is a disease caused by the growth of abnormal cells. These cells are formed due to the mutation of genes that undergo changes, either the shape, size, or function of the original cell. Cancer cells lose their control over cell-cycle regulation and cellular homeostatic function in multicellular organisms so that the cells cannot proliferate normally. As the result, cells will proliferate continuously, resulting in abnormal tissue growth. Several treatments against cancer have been done intensively, such as surgery, chemotherapy and radiotherapy. However, selective cancer treatment which can destroy cancer cells without injuring normal cells are lacking. ${ }^{1-3}$

Natural substances in plants and fruits have the potentials to be developed as anticancer drugs. ${ }^{4,5}$ One of them is Cayratia trifolia ( $C$. trifolia) which is one of the tropical plants belong to the family of Vitaceae. It is a wild plant species that are easy to find in the forest, especially in the riverside. Parts of $C$. trifolia, that is often used are fruit, stem and leaf. It has been used empirically to treat various types of diseases. ${ }^{6,7}$

Antimitotic test is one of the most common

Corresponding author: Eva Feriadi. Faculty of Pharmacy, Halu Oleo University, Kendari, South Sulawesi, Indonesia. Email : eva.feriadi@gmail.com 
toxicity test methods used in the development of bioactive compounds for cancer. In general, cell division that occurs in humans is similar to the cell division that occurs in the eggs of sea urchins or Tripneustes gratilla ( $T$. gratilla). Eggs that undergo fertilization by sperm will go through several stages of cell division. The division process can be impaired by the presence of chemical compound which is toxic to the cells and even causes cells death. The inhibition process of the egg-cells division system can be used as the screening tests for bioactive compounds which possibly has the potential to be of anticancer drugs. The ability of a compound in inhibiting the rate of cells division and growth are often referred as antimitotic activity. ${ }^{8,9}$

This study was aimed to determine antimitotic activity from stem and leaf ethanol extract of C. trifolia to the zygote cell of $T$. gratilla.

\section{Methods}

\section{Materials and instruments}

Materials used in this study included extracts of $C$. trifolia, adult $T$. gratilla obtained from Bokori waters in Soropia District (Kendari), ethanol, protozoa-free water, vincristine, aquadest, DMSO , $\mathrm{KCl}$ and formalin. The instruments used in this study were rotary vacuum evaporator (Rotavapor, Buchi ${ }^{\circledR}$ ), blender (philips), analytical scales (Precisa $\left.{ }^{\circledR}\right)$, measuring cylinders (Pyrex $\left.{ }^{\circledR}\right)$, hot plate (Stuart $\left.{ }^{\circledR}\right)$, erlenmeyer (Pyrex $\left.{ }^{\circledR}\right)$, reaction tubes (Pyrex $\left.{ }^{\circledR}\right)$, beaker glass (Pyrex $\left.{ }^{\circledR}\right)$, measuring flask (Pyrex $\left.{ }^{\circledR}\right)$, aerators, light microscopes, and refrigerators.

\section{Sample determination}

The sample of $C$. trifolia was determined at the Laboratory of Biology Education, Faculty of Education, Halu Oleo University.

\section{Extraction}

Stems and leaves of C.trifolia were washed, cut, dried, and grinded. Maceration was performed in a closed container for $3 \times 24$ hours using ethanol solvent. The solvent evaporation was conducted using a rotary vacuum evaporator at a temperature of $60^{\circ} \mathrm{C}$ until a viscous extract was obtained. Extract characteristics test included determination of water soluble contents, ethanol soluble contents, moisture contents and ash contents.

\section{Phytochemical screening}

Phytochemical screening was performed using thin layer chromatography (TLC) method using a silica gel plate GF254. The size of each plate was $1 \times 10 \mathrm{~cm}^{2}$. The extract was put $\pm 1 \mathrm{~cm}$ from the bottom of the plate. It was eluted with n-hexane and ethyl acetate $(8: 2)$ solution. After the mobile phase reached the boundary line, elution was stopped. To observe the class of compounds contained in each extract, reagent markers were sprayed to the plate. The stains on the surface of the plate were examined under UV light at wavelengths of $254 \mathrm{~nm}$ and $366 \mathrm{~nm}$.

\section{Antimitotic activity}

a. Fertilization

T. gratilla (male and female) were injected by $1 \mathrm{ml}$ of $10 \% \mathrm{KCl}$ into their gonads. The milk-white sperm and the yellow golden egg were put in different glasses. Fertilization was performed by adding $1 \mathrm{ml}$ of sperm and $4 \mathrm{ml}$ of eggs in a glass containing $50 \mathrm{ml}$ of protozoa-free sea water. It was put in refrigerator at $7^{\circ} \mathrm{C}$ and left for 90 minutes.

b. Sample preparation

$5 \mathrm{mg}$ of $C$. trifolia leaves and stems extracts were dissolved in $500 \mathrm{ml}$ DMSO and diluted with protozoa-free seawater to obtain $1000 \mu \mathrm{g} / \mathrm{ml}$ concentration as stock solution. This stock solution was pipetted using a micropipette into the vial to obtain concentrations of $50,100,200$, 400 and $800 \mu \mathrm{g} / \mathrm{ml}$. The negative control 
Table 1. Extract characterization

\begin{tabular}{llcccc}
\hline & Water Content & Ash Content & $\begin{array}{c}\text { Water Soluble } \\
\text { Content }\end{array}$ & $\begin{array}{c}\text { Ethanol Solu- } \\
\text { ble Content }\end{array}$ \\
\hline Cayratia & Stems & $5.59 \%$ & $5.04 \%$ & $26 \%$ & $30 \%$ \\
trifolia & Leaves & $6.89 \%$ & $5.70 \%$ & $24 \%$ & $30 \%$ \\
& Standard & $<10 \%$ & $<6 \%$ & $>18 \%$ & $12,5 \%$ \\
\hline
\end{tabular}

was made (without any compound) by using protozoa-free water. Vincristine drug used as positive control with various concentration, i.e., $0.01,0.1$, and $1 \mu \mathrm{g} / \mathrm{ml}$.

c. Test treatment

$10 \mu \mathrm{l}$ of each variation of stems and leaves extract concentration of $C$. trifolia and vincristine were pipetted and added with $890 \mu \mathrm{l}$ of protozoa-free seawater and $100 \mu \mathrm{l}$ of fertilized egg. It was then incubated at $7^{\circ} \mathrm{C}$. After incubation for 2 hours, $10 \mu \mathrm{l}$ of formalin $10 \%$ was added to each concentration. $100 \mu \mathrm{l}$ mixture was taken and observed under a microscope at 10x magnification.

d. Data analysis

Data obtained was made in tabular form. The level of antimitotic activity was determined from the percentage of inhibition of non-divided cells. The data was converted into the probit value table to get the $\mathrm{IC}_{50}$ value.

\section{Results And Discussion}

\section{Sample determination}

The determination of sample was conducted using the reference of Plant Taxonomy. ${ }^{10}$ Key determination was: 1a-2a-3b-4a-5b. Based on analysis, the sample used was $C$. trifolia.

\section{Extraction}

365.6 grams of leaves powder and 347.6 grams of stems powder were obtained. The extraction resulted in $77.82 \mathrm{~g}$ of stems concentrated extract and $82.30 \mathrm{~g}$ of leaves concentrated extract with the yield of $22.38 \%$ and $22.50 \%$, respectively. The characteritistics of the extract is shown in table 1. The result showed that water content, ash content, water-soluble content, and ethanol-soluble content of our extract complied the standard. The determination of water content is very important because high amount of water can trigger bacteria and fungi growth which can damage the compound contained in the extract. The determination of total ash content was performed to provide an overview of internal and external mineral content derived from the initial process until the formation of the extract. Total ash content associated with minerals either organic or inorganic compounds. The determination of water soluble and ethanol content is important to provide an initial information on the amount of the compound which can be sought with water solvents and ethanol from an extract.

Table 2. The results of phytochemical screening

\begin{tabular}{|c|c|c|c|c|c|c|}
\hline \multirow[b]{2}{*}{ Sample } & \multirow{2}{*}{$\begin{array}{c}\text { Parts of } \\
\text { plant }\end{array}$} & \multicolumn{5}{|c|}{ Secondary Metabolites } \\
\hline & & Alkaloid & Flavonoid & Tannin & Saponin & $\begin{array}{c}\text { Triterpe- } \\
\text { noide }\end{array}$ \\
\hline
\end{tabular}




\section{Phytochemical screening}

Phytochemical screening is a qualitative analysis conducted to determine the chemical content of a plant. In current study, we used TLC method because it has several advantages, including perfect separation, higher sensitivity, and allow multiplecomponent analysis which make the screening time is relatively short. One of the methods to observe the class of compounds contained in each part of the plant can be examined by spraying the reagent marker to the plate. We found that both extracts contained alkaloid, flavonoid, tannin, saponin, and triterpenoid.

\section{Antimitotic activity}

One of the preliminary test to identify anticancer activity is antimitotic activity test. Although mitosis is the shortest phase and only one part of the cell cycle, it is one of the most important phases of the cell cycle because in this phase, the cell undergoes division to produce new cells. Cancer cells resemble the growth in zygote cells. ${ }^{12}$ Both types of cells begin the cell cycle process at the growing period (G1), then phase S (DNA synthesis) then to the second growing phase (G2) before the next mitosis occurs. In addition, cell division that occurs in humans is similar to the division that occurs in zygote cells of sea urchins. Therefore, the inhibitory process of the zygote cells division is considered as one of the alternative methods that can be used to determine the initial activity of a compound against cell division. ${ }^{13}$

An important stage in the determination of antimitotic activity is fertilization. The process of fertilization can be defined as the fusion of the egg (ovum) and the sperm cells to produce a zygote, which then develops into an embryo or fetus of an organism. The process of fertilization in this study was done by inducing $1 \mathrm{ml}$ of $10 \% \mathrm{KCl}$ into male and female sea urchins through the mouth so that the sperm and egg cells would pass through the anus. $\mathrm{KCl}$ solution is hypotonic solution, i.e., the concentration of $\mathrm{KCl}$ solution is lower than the concentration inside the cells. This situation caused the stimulation of the cells which resulted in the breaking of the cell walls. The process of fertilization can be seen in Figure 1.

Sperm cells that have hydrolytic enzymes were able to make acrosomal prolapse that can penetrate to the jelly layer of the egg cell. This acrosomal reaction causes the fusion of nucleus of sperm cell to the egg cytoplasm. The fusion of the membrane generates an electrical response by the egg's plasma membrane. The ion channels open up so that

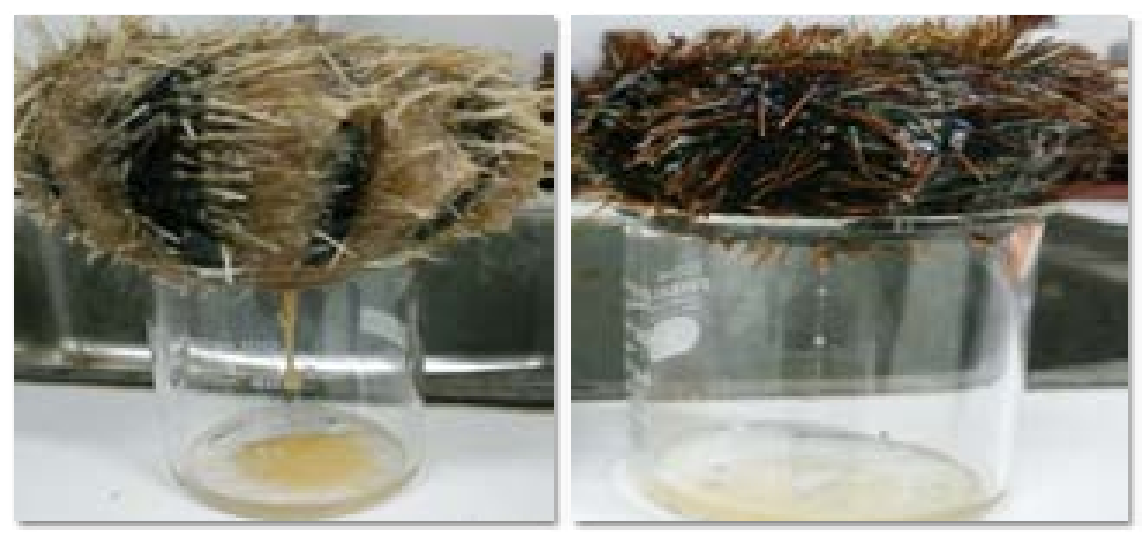

Figure 1. Fertilization process of ovum cells (a), and sperm cells (b) 
the sodium ions can flow into the egg and alter the membrane potential. This occurs 1 to 3 seconds after the sperm cells bind to the vitellin coating.

Several factors should be considered to perform successful fertilization process. Previous studies showed that the level of gonad maturity, fertilization media, temperature and salinity influenced this process. Each of these factors plays an important role in the success or failure of the fertilization process. The maturity level of the gonads should be in the range of TKG-4 (mature). The fertilization media must also be free of protozoa that can disrupt the fertilization process. In addition, the temperature factor is also influential in the fertilization process. In this study the temperature used was $7^{\circ} \mathrm{C}$. The temperature adjusts to the habitat conditions in which $T$. gratilla do external fertilization.

Initial treatment was conducted by adding the extract, control positive, and negative to the zygote cells for 2 hours. Antimitotic activity was observed using microscope
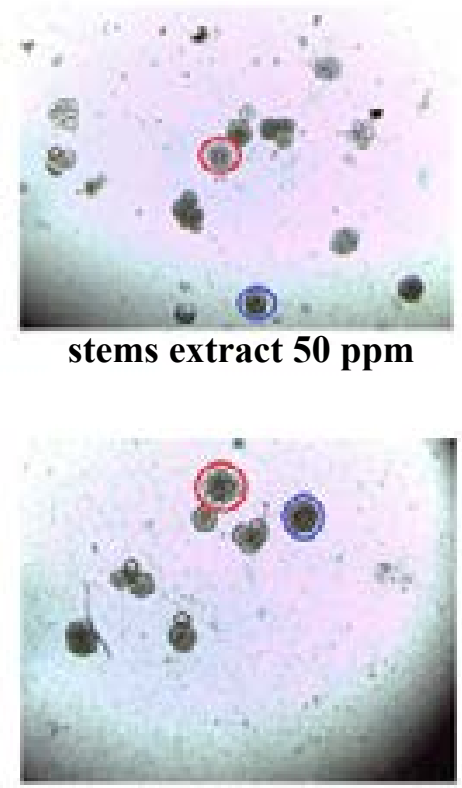

leaves extract $50 \mathrm{ppm}$

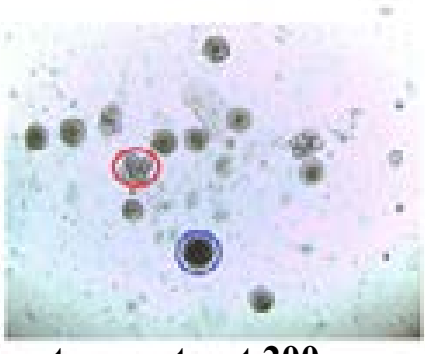

stems extract $200 \mathrm{ppm}$

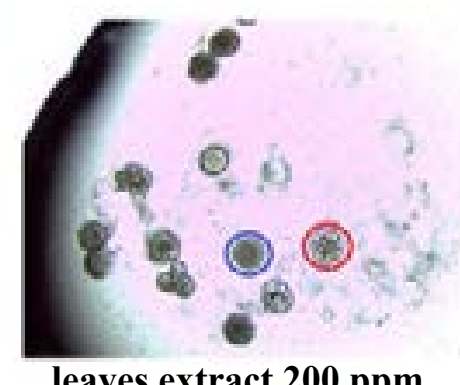

leaves extract $200 \mathrm{ppm}$
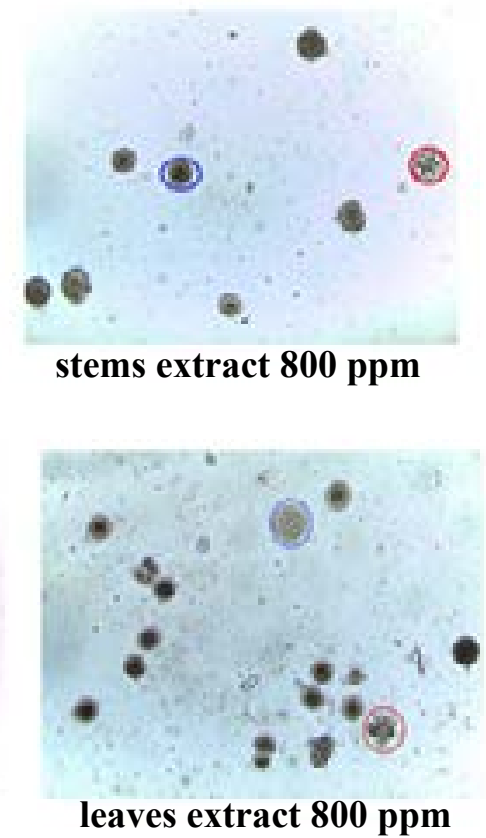
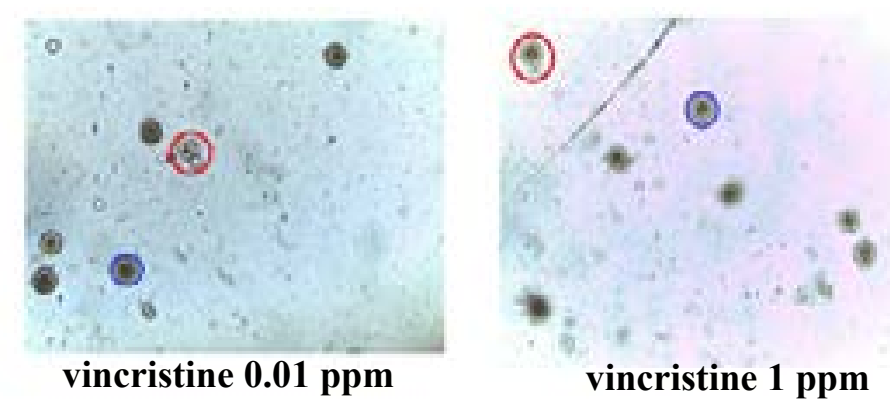

Figure 2. Antimitotic activity of $C$. trifolia and vincristine Cell divided: red circle, cell did not divide: blue circle. 
Table 3. Antimitotic category ${ }^{10}$

\begin{tabular}{ll}
\hline Category & $\mathrm{IC}_{50}(\mu \mathrm{g} / \mathrm{ml})$ \\
\hline Very strong & $<10$ \\
Strong & $10-100$ \\
Moderate & $100-500$ \\
\hline
\end{tabular}

with ten times magnification. The higher the concentration of the extract, more zygote cells growth were inhibited. The $\mathrm{IC}_{50}$ value of the sample can be determined using the linear regression equation. In the antimitotic activity test, inhibition of cell division was calculated as $\mathrm{IC}_{50}$ value as the concentration required to inhibit cell growth by $50 \%$. The category of antimitotic activity based on $\mathrm{IC}_{50}$ values can be seen in Table 2. The smaller the $\mathrm{IC}_{50}$ value means the stronger the antimitotic activity.

Different $\mathrm{IC}_{50}$ value was observed between stems and leaves extract. Stems extract had $\mathrm{IC}_{50}$ value of $169.82 \mu \mathrm{g} / \mathrm{ml}$, while leaves extract had $\mathrm{IC}_{50}$ value equal to $208.92 \mu \mathrm{g} / \mathrm{ml}$. The positive control of vincristine had $\mathrm{IC}_{50}$ value of $3.23 .10^{-3} \mu \mathrm{g} / \mathrm{ml}$, indicating that vincristine had a very strong antimitotic activity. Based on the antimitotic category on Table 3, the antimitotic activity of both extracts were classified into the moderate category. Secondary metabolites such as alkaloid, flavonoid, and triterpenoides might contribute in the antimitotic activity of $C$. trifolia. ${ }^{14-16}$

\section{Conclusion}

The ethanol extract of stems and leaves of C. trifolia had moderate antimitotic activity against cell division of T.gratilla, with the $\mathrm{IC}_{50}$ value of $169.82 \mu \mathrm{g} / \mathrm{ml}$ and $208.92 \mu \mathrm{g} /$ $\mathrm{ml}$, respectively. Further research is needed to investigate their activities against cancer cell culture to prove further cytotoxic activity and its mechanism in inhibiting the mitosis of cancer cells.

\section{References}

1. Deberardinis RJ. Is cancer a disease of abnormal cellular metabolism? new angles on an old idea. Genetics in Medicines. 2008;10(11):767-777.

2. Xie Y, Wolff DW, Wei T, Wang B. Breast cancer migration and invasion depend on proteasome degradation of regulator of G-protein signaling. Cancer Research. 2009;69:5743-5751

3. Thompson SL, Compton DA. Chromosomes and cancer cells. Chromosome Research. 2011;19:433444.

4. Safarzadeh E, Sandoghchian S, Baradaran B. Herbal medicine as inducers of apoptosis in cancer treatment. Advanced Pharmaceutical Bulletin. 2014;4(Suppl 1):421-427.

5. Yin SY, Wei WC, Jian FY, Yang NS. Therapeutic applications of herbal medicines for cancer patients. Evidencebased Complementary and Alternative Medicine. 2013;20:302.

6. Kumar D, Gupta J, Kumar S, Arya R. Pharmacognostic evaluation of Cayratia trifolia (Linn.) leaf. Asian Pacific Journal of Tropical Biomedicines. 2012;2:6-10.

7. Kumar D, Gupta J. A review on chemical and biological properties of Cayratia trifolia Linn. (Vitaceae). Pharmacognosy Reviews. 2011;5(10):184-188.

8. Santana GM, Deus MSM, Sousa JMC, Ferreira PMP, Fernandes HB. Antimitotic and antimutagenic action of the Hymenaea stigonocarpa bark on dividing cells. Brazilian Journal of Biology. 2016;76:520-525. 
9. Van-vuuren RJ, Visagie $\mathrm{MH}$, Theron AE, Joubert AM. Antimitotic drugs in the treatment of cancer. Cancer Chemotherapy and Pharmacology. 2015;76:1101-1112.

10. Tjitrosoepomo G. 2011. Plant Taxonomy. Yogyakarta: Gajah Mada University Press.

11. Weerapreyakul N, Nonpunya A, Barusrux $\mathrm{S}$. Evaluation of the anticancer potential of six herbs againts a hepatoma cell line. Chinese Medicine. 2012;7(15):2-7.

12. Neumüller RA, Knoblich JA. Dividing cellular asymmetry: asymmetric cell division and its implications for stem cells and cancer. Genes \& Development. 2009;23(23):2675-2699.

13. Leite JC, Junior CG, Silva FP. Antimitotic activity on sea urchin embryonic cells of seven antiparasitic Morita-BaylisHillman adducts: a potential new class of anticancer drugs. Medicinal Chemistry. 2012;8:1003-1011.

14. Chahar MK, Sharma N, Dobhal MP, Joshi YC. Flavonoids: a versatile source of anticancer drugs. Pharmacognosy Reviews. 2011;5(9):1-12.

15. Jin L, Jiao LB, Xiu PC. Alkaloids isolated from natural herbs as the anticancer agents. Evidence-Based Complementary and Alternative Medicine. 2012;12:1220.

16. Thoppil RJ, Bishayee A. Terpenoids as potential chemopreventive and therapeutic agents in liver cancer. World Journal of Hepatology. 2011;3(9):228249. 